\title{
Contribution of different grass species to plant-atmosphere ammonia exchange in intensively managed grassland
}

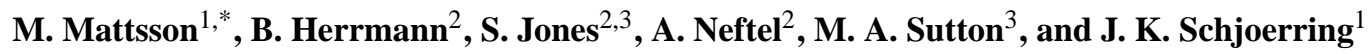 \\ ${ }^{1}$ Plant and Soil Science Laboratory, University of Copenhagen, Faculty of Life Sciences, Thorvaldsensvej 40, \\ 1871 Frederiksberg C, Copenhagen, Denmark \\ ${ }^{2}$ Agroscope Reckenholz-Tänikon Research Station ART, Reckenholzstrasse 191, 8046 Zürich, Switzerland \\ ${ }^{3}$ Natural Environmental Research Council, Centre for Ecology and Hydrology, Edinburgh Research Station, \\ Penicuik EH26 0QB, Midlothian Scotland \\ *now at: Section for Economy and Technology, Halmstad University, Halmstad, 30118 Sweden
}

Received: 5 May 2008 - Published in Biogeosciences Discuss.: 17 June 2008

Revised: 4 December 2008 - Accepted: 4 December 2008 - Published: 9 January 2009

\begin{abstract}
Species diversity in grasslands usually declines with increasing input of nitrogen from fertilizers or atmospheric deposition. Conversely, species diversity may also impact the build-up of soil and plant nitrogen pools. One important pool is $\mathrm{NH}_{3} / \mathrm{NH}_{4}^{+}$which also can be exchanged between plant leaves and the atmosphere. Limited information is available on how plant-atmosphere ammonia exchange is related to species diversity in grasslands. We have here investigated grass species abundance and different foliar nitrogen pools in 4-year-old intensively managed grassland. Apoplastic $\mathrm{pH}$ and $\mathrm{NH}_{4}^{+}$concentrations of the 8 most abundant species (Lolium perenne, Phleum pratense, Festuca pratensis, Lolium multiflorum, Poa pratensis, Dactylis glomerata, Holcus lanatus, Bromus mollis) were used to calculate stomatal $\mathrm{NH}_{3}$ compensation points. Apoplastic $\mathrm{NH}_{4}^{+}$concentrations differed considerably among the species, ranging from 13 to $117 \mu \mathrm{M}$, with highest values in Festuca pratensis. Also apoplastic $\mathrm{pH}$ values varied, from $\mathrm{pH} 6.0$ in Phleum pratense to 6.9 in Dactylis glomerata. The observed differences in apoplastic $\mathrm{NH}_{4}^{+}$and $\mathrm{pH}$ resulted in a large span of predicted values for the stomatal $\mathrm{NH}_{3}$ compensation point which ranged between 0.20 and $6.57 \mathrm{nmol} \mathrm{mol}^{-1}$. Three species (Lolium perenne, Festuca pratensis and Dactylis glomerata) had sufficiently high $\mathrm{NH}_{3}$ compensation point and abundance to contribute to the bi-directional $\mathrm{NH}_{3}$ fluxes recorded over the whole field. The other 5 grass species had $\mathrm{NH}_{3}$ compensation points considerably below the atmospheric $\mathrm{NH}_{3}$ concentration and were thus not likely to con-
\end{abstract}

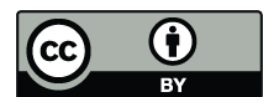

Correspondence to: J. K. Schjoerring (jks@life.ku.dk) tribute to $\mathrm{NH}_{3}$ emission but only to $\mathrm{NH}_{3}$ uptake from the atmosphere. Evaluated across species, leaf bulk-tissue $\mathrm{NH}_{4}^{+}$ concentrations correlated well $\left(r^{2}=0.902\right)$ with stomatal $\mathrm{NH}_{3}$ compensation points calculated on the basis of the apoplastic bioassay. This suggests that leaf tissue $\mathrm{NH}_{4}^{+}$concentrations combined with data for the frequency distribution of the corresponding species can be used for predicting the $\mathrm{NH}_{3}$ exchange potential of a mixed grass sward.

\section{Introduction}

The diversity of species in grasslands depends on a range of management and environmental factors (Cleland et al., 2006; Klimek et al., 2007; Pywell et al., 2007). In the short term, the initial composition of the seed mixture sown determines the proportion of different species in grasslands (Bullock et al., 2007), while in the longer term other management factors such as cutting frequency (Pontes et al., 2007; Critchley et al., 2007), fertilization (Hill and Carey, 1997; Oelmann et al., 2007) and liming (Silvertown et al., 2006) become important. Species diversity is usually reduced with increasing amounts of $\mathrm{N}$ fertilization (Clark et al., 2007; Harpole et al., 2007). Moderate to high rates of fertilizer $N$ stimulate the more productive grass species, such as Lolium perenne and Dactylis glomerata (Whitehead, 1995; Hill et al., 2005). Increasing levels of atmospheric nitrogen deposition can also contribute to loss of species diversity (Stevens et al., 2004, 2006). With increasing age of the sward, the proportion of perennial ryegrass and other cultivated species will decline, and the number of indigenous species will increase (Hopkins, 1986; Critchley et al., 2002).

Published by Copernicus Publications on behalf of the European Geosciences Union. 
There is a reciprocal relationship between species diversity and nitrogen abundance in grasslands: On the one hand, enhanced $\mathrm{N}$ input reduces species richness, while on the other hand the composition of grassland swards may affect the size of different soil and plant nitrogen pools (Oelmann et al., 2007). Limited information is available on how plantatmosphere exchange of ammonia in grasslands is related to species diversity.

Studies of different grass species in cuvette systems under controlled laboratory conditions have shown that they can differ in both the rate of $\mathrm{NH}_{3}$ exchange and in how the exchange is influenced by $\mathrm{N}$ nutrition (Hanstein et al., 1999; Mattsson and Schjoerring, 2002). Under field conditions, micrometeorological methods (Milford et al., 2008) and dynamic cuvette measurements (David et al., 2008) are used to study the exchange of ammonia between grassland vegetation and the atmosphere. However, none of these two approaches are able to distinguish between contributions from different species in a mixed canopy. An additional problem with micrometeorological measurements over grassland is that it is not possible with existing technology to separate between $\mathrm{NH}_{3}$ emission from the foliage and emission from litter or soil.

Measurements of apoplastic $\mathrm{NH}_{4}^{+}$and $\mathrm{H}^{+}$concentrations under laboratory conditions (Husted and Schjoerring, 1995, 1996; Mattsson et al., 1997, 1998; Hanstein et al., 1999; Hill et al., 2001; Mattsson and Schjoerring, 2002) or in the field (Husted et al., 2000; Herrmann et al., 2001; van Hove et al., 2002; Loubet et al., 2002) have been useful for estimating the ammonia exchange potential of different species growing under different conditions. In order to develop more simple bio-indicators than those based on extraction of apoplastic solution it is essential to get information on the relationship between the stomatal $\mathrm{NH}_{3}$ compensation point and other plant $\mathrm{N}$ pools. However, there is a limit to how simple things can be made as the total $\mathrm{N}$ content of the leaf tissue seems to be an inadequate parameter for prediction of the potential $\mathrm{NH}_{3}$ emission from rye grass leaves (van Hove et al., 2002).

The aim of the present study was to measure different $\mathrm{N}$ parameters of the 8 most abundant species growing in a grass field. Apoplastic solution was analysed and the results used to predict the stomatal $\mathrm{NH}_{3}$ compensation point for the different species. In addition, the concentrations of leaf bulktissue $\mathrm{NH}_{4}^{+}$, total soluble $\mathrm{N}$ and total $\mathrm{N}$ were measured and their correlation with the stomatal $\mathrm{NH}_{3}$ compensation point analysed.

\section{Materials and methods}

\subsection{Description of the measurement site}

The investigation took place as part of the GRAMINAE integrated experiment between 22 May and 15 June 2000 (Sutton et al., 2008). The field site was located near Braunschweig in
Lower Saxony, Germany. The field was $600 \times 300 \mathrm{~m}$ in size and consisted of a mixed sward. The field had been grassland for 4 years, receiving typically $250-350 \mathrm{~kg} \mathrm{~N} \mathrm{ha}^{-1} \mathrm{yr}^{-1}$. Some extra Lolium perenne seeds $(20 \mathrm{~kg} / \mathrm{ha})$ had been intersown 2 months before the experiment. Plant species cover was assessed by point contact sampling at 20 points which were identified by a random walk between subsequent sampling points using four direction options and distances between 1 and $10 \mathrm{~m}$ (Knapp, 1984).

\subsection{Sampling of plant material}

Fully developed green leaves of the 8 most abundant grass species (Lolium perenne, Phleum pratense, Festuca pratensis, Lolium multiflorum, Poa pratensis, Dactylis glomerata, Holcus lanatus, Bromus mollis) were collected around noon on the 24 and 25 May 2000 for apoplastic $\mathrm{pH}$ and $\mathrm{NH}_{4}^{+}$measurements. The plant material was collected randomly in the field and immediately brought to an adjacent field laboratory. Some leaves were immediately used for extraction of apoplastic solution and the rest were frozen in liquid nitrogen and stored at $-20^{\circ} \mathrm{C}$ for later determination of tissue $\mathrm{NH}_{4}^{+}$, $\mathrm{NO}_{3}^{-}$and total soluble $\mathrm{N}$. For analysis of total $\mathrm{N}$ concentration, plant material was dried at $60^{\circ} \mathrm{C}$ for $24 \mathrm{~h}$.

\subsection{Extraction of apoplastic solution}

Apoplast liquid was extracted by means of vacuum infiltration according to Husted and Schjoerring (1995). Whole leaf laminas were infiltrated with $280 \mathrm{mM}$ sorbitol solution at a pressure of $16 \mathrm{bar}$ and under vacuum for $5 \mathrm{~s}$. This procedure was repeated 5 times. After infiltration, solution on leaf surfaces was removed by use of paper towels, whereupon the leaves were packed into plastic bags and left for $20 \mathrm{~min}$ in daylight in order to allow the apoplastic $\mathrm{NH}_{4}^{+}$ and $\mathrm{H}^{+}$concentrations to reach equilibrium after infiltration. Thereafter, the leaves were centrifuged for $10 \mathrm{~min}$ at $4^{\circ} \mathrm{C}$ and $800 \mathrm{~g}$. Concentrations of $\mathrm{NH}_{4}^{+}$in the extracted solution were determined by flow injection analysis (FIA) using $o$-phthalaldehyde (OPA) as reagent (Genfa et al., 1989). Apoplastic $\mathrm{pH}$ was measured with a Micro-Combination $\mathrm{pH}$ electrode (type 9810, Orion, Beverly, USA). In order to assess cytoplasmic contamination of the apoplastic solution, malate dehydrogenase (MDH; E.C. 1.1.1.38) activity was determined and compared with the activity measured in bulk leaf extracts (Husted and Schjoerring, 1995). MDH activity of the apoplastic solution relative to bulk leaf extract was generally $<1 \%$.

\subsection{Calculation of stomatal $\mathrm{NH}_{3}$ compensation points}

The stomatal $\mathrm{NH}_{3}$ compensation point $\left(\chi_{\mathrm{NH}_{3}}\right.$, mol $\mathrm{NH}_{3} \mathrm{~mol}^{-1}$ air) at $25^{\circ} \mathrm{C}$ was calculated by use of Eq. (1) derived from Husted and Schjoerring (1996) taking into 
account that $K_{d} \ll\left[\mathrm{H}^{+}\right]_{\text {apoplast }}$ within the range of apoplastic $\mathrm{pH}$ values:

$$
{ }^{25} \chi_{\mathrm{NH}_{3}}=K_{H .25} \times K_{d .25} \times \Gamma=10^{-11.01} \times \Gamma
$$

$\Gamma$ is the dimensionless ratio between the apoplastic $\mathrm{NH}_{4}^{+}$and $\mathrm{H}^{+}$concentrations, and $K_{H}$ and $K_{d}$ are thermodynamic constants of $10^{-1.76} \mathrm{~atm} 1 \mathrm{~mol}^{-1}$ and $10^{-9.25} \mathrm{moll}^{-1}$ at $25^{\circ} \mathrm{C}$, respectively. Equation (1) literally calculates the pressure of $\mathrm{NH}_{3}$ (unit: atm), which according to Dalton's law of partial pressures is equal to the mol fraction (or volume fraction) at a given atmospheric pressure.

The calculated $\chi_{\mathrm{NH}_{3}}$ at $25^{\circ} \mathrm{C}\left(T_{\text {ref }}\right)$ was adjusted to the actual canopy temperature $\mathrm{T}_{c}$ by the following equation derived from Husted and Schjoerring (1996):

$\ln \left({ }^{T_{C}} \chi_{\mathrm{NH}_{3}} T^{T_{\mathrm{ref}}} \chi_{\mathrm{NH}_{3}}\right)=\left(\Delta H_{\text {dis }}^{0}+\Delta H_{\mathrm{vap}}^{0}\right) / R \times$

$\left(1 / T_{\text {ref }}-1 / T_{c}\right)=34.868-10395.91 / T_{c}$

$T_{c} \chi_{\mathrm{NH}_{3}}$ is the requested $\mathrm{NH}_{3}$ compensation point at the actual canopy temperature $T_{c}(K), \Delta \mathrm{H}_{\mathrm{dis}}^{0}$ the enthalpy of $\mathrm{NH}_{4}^{+}$dissociation $\left(52.21 \mathrm{~kJ} \mathrm{~mol}^{-1}\right), \Delta \mathrm{H}_{\text {vap }}^{0}$ the enthalpy of vaporization $\left(34.18 \mathrm{~kJ} \mathrm{~mol}^{-1}\right)$, and $R$ the gas constant $\left(0.00831 \mathrm{~kJ} \mathrm{~K}^{-1} \mathrm{~mol}^{-1}\right)$. The canopy temperature, measured by attached sensors as well as infra-red detection, was 16.7 and $20.7^{\circ} \mathrm{C}$ around noon on 24 and 25 May, respectively. Following the ideal gas law, an $\mathrm{NH}_{3}$ compensation point of $1 \mathrm{nmol} \mathrm{mol}^{-1}$ air corresponds to $0.71 \mu \mathrm{g} \mathrm{NH}_{3} \mathrm{~m}^{-3}$ at $20^{\circ} \mathrm{C}$.

\subsection{Analysis of bulk tissue $\mathrm{NH}_{4}^{+}, \mathrm{NO}_{3}^{-}, \mathrm{pH}$, total $\mathrm{N}$ and $\mathrm{C}$}

Frozen leaf samples were homogenised in $10 \mathrm{mM}$ formic acid in a cooled mortar with a little sand. The homogenate was centrifuged at $25000 \mathrm{~g}\left(2^{\circ} \mathrm{C}\right)$ for $10 \mathrm{~min}$ and the supernatant was transferred to $500-\mu 10.45 \mu \mathrm{m}$ polysulphone centrifugation filters (Micro VectraSpin, Whatman Ltd., Maidstone, UK) and spun at $5000 \mathrm{~g}\left(2^{\circ} \mathrm{C}\right)$ for $5 \mathrm{~min}$ (Husted et al., 2000b). The filtered solution was used for analysis of $\mathrm{NO}_{3}^{-}$and $\mathrm{NH}_{4}^{+}$concentrations on a flow injection system (Quick Chem instrument, Lachat Istruments INC, Milwaukee, USA). For bulk tissue $\mathrm{pH}$ measurements, $0.2 \mathrm{~g}$ sample of leaf material was homogenized in $2 \mathrm{ml}$ of deionized water in a cooled mortar with a little sand. The homogenate was centrifuged at $14000 \mathrm{~g}\left(4^{\circ} \mathrm{C}\right)$ for $10 \mathrm{~min}$ and $\mathrm{pH}$ in the supernatant measured with a microelectrode (Metrohm, Herisau, Switzerland). Tissue extracts were also analysed for total soluble $\mathrm{N}$ concentration (so-called substrate $\mathrm{N}$ ) using an ANCA-SL Elemental Analyser coupled to a 20-20 Tracermass Mass Spectrometer (SerCon Ltd., Crewe, UK). The same equipment was used for analysis of total $\mathrm{N}$ and $\mathrm{C}$ concentrations in oven dried plant material ground to a fine powder.

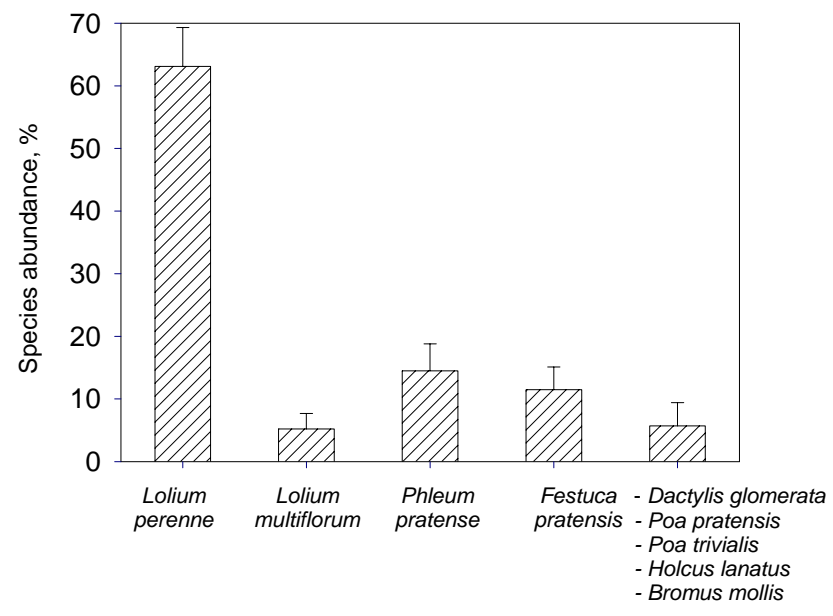

Fig. 1. Plant species abundance in a 4-year-old intensively managed grassland at Braunschweig, Germany. Data are means of 20 replicates $\pm \mathrm{SE}$.

\section{Results}

\subsection{Species diversity}

The field site consisted of nine grass species, dominated by Lolium perenne and followed by Phleum pratense, Festuca pratensis and Lolium multiflorum (Fig. 1). Other grass species accounted for less than $10 \%$ of the total species composition. Relative to the composition of the seed mixture sown four years earlier (Sutton et al., 2008), Lolium perenne had increased in abundance from $29 \%$ to $63 \%$, while Festuca pratensis and Poa pratensis had decreased from 33 to $11 \%$ and 12 to $<5 \%$, respectively. Phleum pratense had maintained approximately the same abundance as in the seed mixture. Lolium multiflorum, Dactylis glomerata, Poa trivialis, Holcus lanatus and Bromus mollis were not sown at all and must therefore be considered as invading species. Festuca rubra and Trifolium repens was also part of the seed mixture but had almost disappeared. All of the species measured were perennial grasses except the biennial Lolium multiflorum and the annual Bromus mollis (Table 1).

Using the standard set of indicator values for the Central European flora of Ellenberg (Ellenberg et al., 1991), the nitrogen preference of the different species in the experimental sward was compared. Lolium perenne had the highest $\mathrm{N}$ indicator value (Table 1) showing that this is a species found on rich fertile sites, while Bromus mollis had the lowest $\mathrm{N}$ value showing preference for nitrogen-poor sites (Table 1). The tendency of the species to dominate the sward was also compared on the basis of Ellenberg indicator values for dominance (Table 1). The observed richness of Lolium perenne (Fig. 1) was in agreement with the relatively high dominance indicator value for this species (Table 1). Also Holcus lanatus has a high dominance indicator value (Table 1) but was nevertheless only present in low abundance (Fig. 1) reflecting 
Table 1. Life-cycle and Ellenberg indicator values on a scale from 1 to 9 for the 8 most abundant species growing in a 4-year-old intensively managed grassland at Braunschweig, Germany.

\begin{tabular}{llllll}
\hline Species & & & & & \\
\hline & Life-cycle & Dominance & N & R & F \\
\hline Lolium perenne & perennial & 6 & 7 & 7 & 5 \\
Dactylis glomerata & perennial & 5 & 6 & $\mathrm{X}$ & 5 \\
Phleum pratense & perennial & 5 & 6 & 7 & 5 \\
Holcus lanatus & perennial & 6 & 4 & $\mathrm{X}$ & 6 \\
Festuca pratensis & perennial & 5 & 6 & $\mathrm{X}$ & 6 \\
Bromus mollis (hordeaceus) & annual & 4 & 3 & $\mathrm{X}$ & $\mathrm{y}$ \\
Lolium multiflorum & biennial & 4 & 6 & 7 & 4 \\
Poa pratensis & perennial & $?$ & 6 & $\mathrm{X}$ & 5 \\
\hline
\end{tabular}

Dominance indicates tendency for dominating a sward (6: the species can dominate). Dominance is not known for Poa pratensis. $\mathrm{N}$ indicates preference for high or low $\mathrm{N}$ fertility (7: species found on highly fertile soil). $\mathrm{R}$ indicates preference for high or low soil $\mathrm{pH}$ (7: species found on neutral $\mathrm{pH}$ soils, never found on acid soils; $\mathrm{X}$ denotes high tolerance to both acidic and alkaline soils). $\mathrm{F}$ indicates preference for soil moisture conditions (5: moist-site indicator but not found on wet soils; y denotes high tolerance to both moist and dry conditions).

the fact that it was not initially sown in the field. The three species Lolium perenne, Phleum pratense and Lolium multiflorum that were most abundant in the sward (Fig. 1) had according to their Ellenberg indicator values preference for neutral soil $\mathrm{pH}$ and fairly moist soil (Table 1) matching the actual conditions at the field site (Sutton et al., 2008). Extra Lolium perenne seeds $(20 \mathrm{~kg} / \mathrm{ha})$ had been intersown 2 months before the experiment and may have contributed to the high relatively abundance of this species although it usually establishes rather slowly in an existing sward.

\section{2 $\mathrm{NH}_{3}$ exchange potential of individual grass species}

In order to assess the potential for $\mathrm{NH}_{3}$ exchange of each of the individual species, stomatal compensation points for $\mathrm{NH}_{3}\left(\chi_{\mathrm{NH}_{3}}\right)$ were estimated on the basis of apoplastic $\mathrm{NH}_{4}^{+}$ concentrations and $\mathrm{pH}$. Apoplastic $\mathrm{NH}_{4}^{+}$concentrations differed considerably among the species, ranging from 13 to $117 \mu \mathrm{M}$, with highest values in Festuca pratensis (Fig. 2a). Also apoplastic $\mathrm{pH}$ values varied among the species, from $\mathrm{pH}$ 6.0 in Phleum pratense to 6.9 in Dactylis glomerata (Fig. 2b). The three species having the highest apoplastic $\mathrm{NH}_{4}^{+}$concentrations also showed the highest apoplastic $\mathrm{pH}$ values. The observed differences in apoplastic $\mathrm{NH}_{4}^{+}$and $\mathrm{pH}$ resulted in a large span of predicted values for $\chi \mathrm{NH}_{3}$ ranging between 0.20 and $6.57 \mathrm{nmol} \mathrm{mol}^{-1}$ (Fig. 3). Lolium perenne, Festuca pratensis and Dactylis glomerata showed many-fold higher $\mathrm{NH}_{3}$ compensation points compared to the rest of the species.

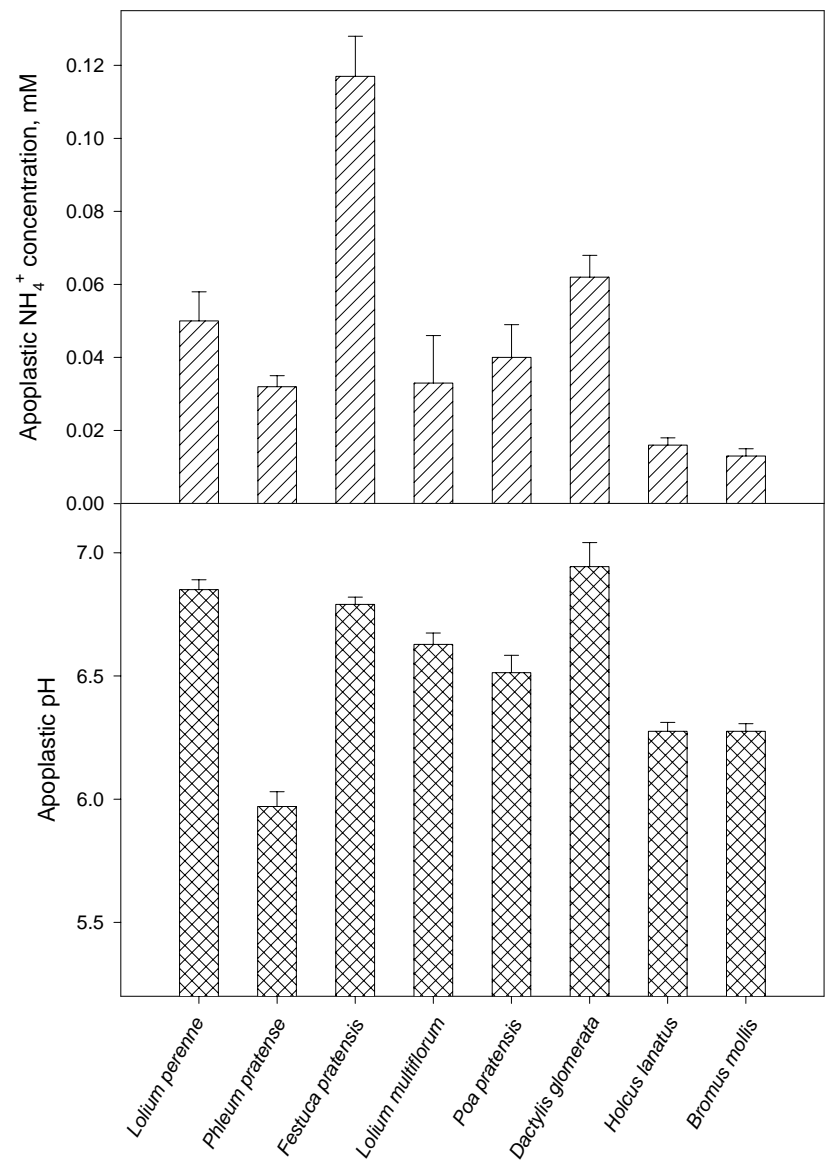

Fig. 2. A. Apoplastic $\mathrm{NH}_{4}^{+}$concentrations and B. apoplastic $\mathrm{pH}$ values of different grass species growing in a 4-year-old intensively managed grassland at Braunschweig, Germany. Values are means $\pm \mathrm{SE}$ of 4 replicates.

\subsection{Tissue level measurements}

Bulk leaf tissue $\mathrm{NH}_{4}^{+}$concentrations were about 25 times higher than the $\mathrm{NH}_{4}^{+}$levels in the apoplastic solution (Fig. 4). The same three species having high apoplastic $\mathrm{NH}_{4}^{+}$concentrations also showed highest bulk leaf tissue $\mathrm{NH}_{4}^{+}$concentrations. Leaf tissue $\mathrm{NO}_{3}^{-}$concentrations were in the same range as the $\mathrm{NH}_{4}^{+}$concentrations with Lolium perenne having the highest value and Phleum pratense the lowest. The $\mathrm{NH}_{4}^{+}$concentrations in bulk leaf tissue extracts of the 7 species (not enough leaf material was sampled of Poa pratensis) were well correlated with the apoplastic $\mathrm{NH}_{4}^{+}$values although the best correlation was found between leaf tissue $\mathrm{NH}_{4}^{+}$concentration and apoplastic $\Gamma$ values (Fig. 5).

Substrate nitrogen, i.e. the total amount of soluble N measured in leaf extracts, also varied between the different species (Table 2). Lolium perenne showed more than twice the concentration of foliar substrate $\mathrm{N}$ compared to Phleum pratense. The linear relationship between tissue $\mathrm{NH}_{4}^{+}$concentration and total soluble $\mathrm{N}$ concentration was 


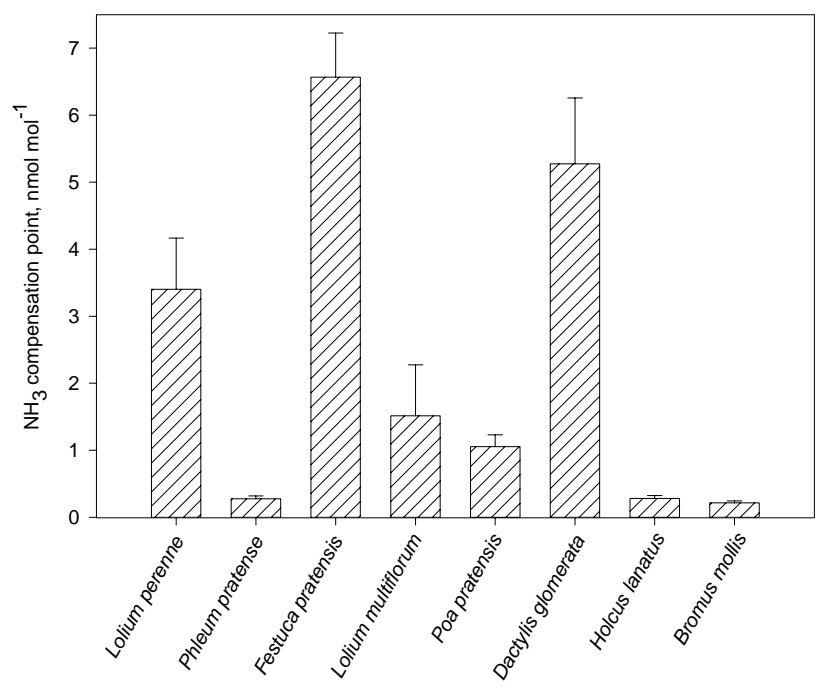

Fig. 3. Ammonia compensation points for 8 different grass species calculated on the basis of apoplastic $\mathrm{NH}_{4}^{+}$and $\mathrm{H}^{+}$concentrations analysed in a 4-year-old intensively managed grassland at Braunschweig, Germany. Values are means \pm SE of 4 replicates.

weak $\left(R^{2}=0.287\right.$, data not shown). Total $\mathrm{N}$ concentration on a dry weight basis ranged from $2.7 \%$ for Phleum pratense to $3.4 \%$ for Bromus mollis. The corresponding C:N ratios ranged between 17.3 and 13.2 (Table 2).

\section{Discussion}

The vacuum infiltration and centrifugation technique for extraction of foliar apoplastic solution enabled for the first time a comparison of the $\mathrm{NH}_{3}$ exchange potential of as many as 8 grass species growing in a mixed sward. The sward was dominated by Lolium perenne (Fig. 1) but contained also a number of other species although $250-350 \mathrm{~kg} \mathrm{~N} \mathrm{ha}^{-1}$ year $^{-1}$ had been applied during the years 1996-2000. It has been shown that the proportion of cultivated species like Lolium perenne increases with the amount of fertilization but decline with age of the sward (Whitehead, 1995). Extraction of apoplastic solution was successfully applied to all plant species using a $280 \mathrm{mM}(350 \mathrm{mOsm})$ sorbitol solution and an incubation time of $20 \mathrm{~min}$ between infiltration and extraction. Lohaus et al. (2001) found that osmolarity and incubation time had a relatively little influence on the composition of the apoplastic solution in 6 plant species.

Although growing in the same habitat, a large variability in apoplastic $\mathrm{NH}_{4}^{+}$concentration occurred between the grass species (Fig. 2a). This may reflect their capability to adapt to the growth conditions of the field and the climatic conditions of the season (Table 1). Holcus lanatus and Bromus mollis having the lowest apoplastic $\mathrm{NH}_{4}^{+}$concentrations are considered low-producing species under conditions of high fertilisation while Lolium perenne and Dactylis glomerata often

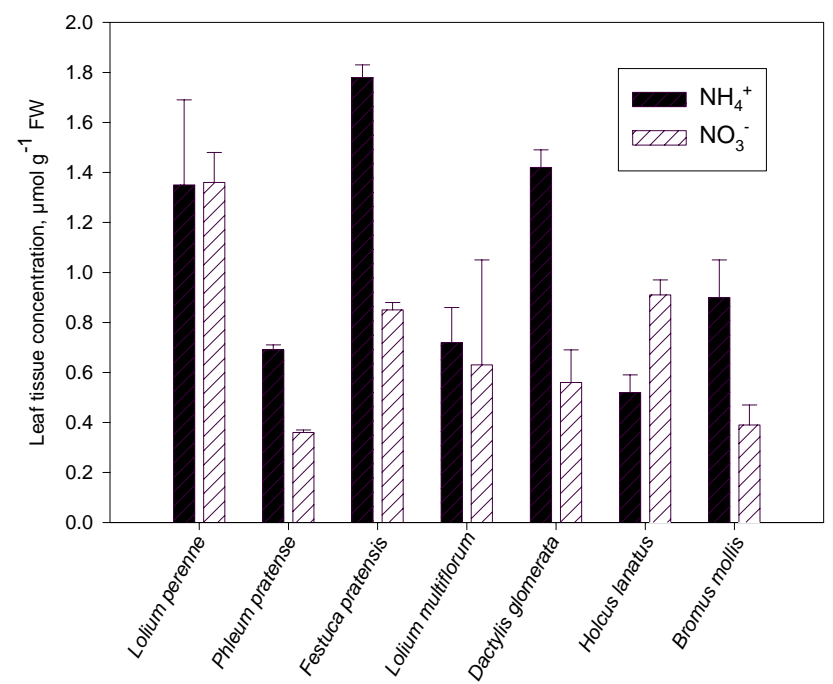

Fig. 4. Bulk leaf tissue $\mathrm{NO}_{3}^{-}$and $\mathrm{NH}_{4}^{+}$concentrations of different species growing in a 4-year-old intensively managed grassland at Braunschweig, Germany. Values are means \pm SE of 4 replicates.

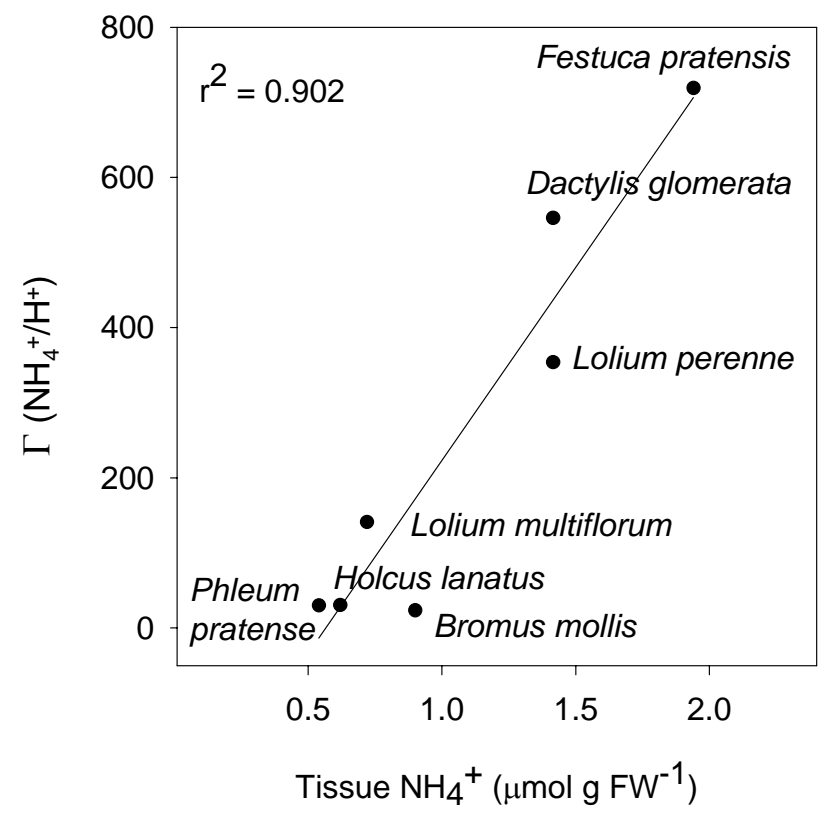

Fig. 5. Correlation between mean bulk leaf $\mathrm{NH}_{4}^{+}$concentration and $\Gamma$ (apoplastic $\mathrm{NH}_{4}^{+} / \mathrm{H}^{+}$) in leaves of different species growing in a 4-year-old intensively managed grassland at Braunschweig, Germany.

produce the highest yields and have the best responses to $\mathrm{N}$ fertilization. Festuca pratensis showed the highest apoplastic $\mathrm{NH}_{4}^{+}$concentration of almost $0.12 \mathrm{mM}$ and Lolium perenne and Dactylis glomerata had about half of that concentration, which is within the same range as apoplastic $\mathrm{NH}_{4}^{+}$concentrations measured in the same two species in a grass/clover sward in Switzerland (Herrmann et al., 2001). Somewhat 
Table 2. Total soluble $\mathrm{N}$ concentration, total $\mathrm{N}$ concentration and $\mathrm{C}: \mathrm{N}$ ratio of fully developed green leaves of different grass species growing in a 4-year-old intensively managed grassland at Braunschweig, Germany. Means of 4 replicates \pm SE.

\begin{tabular}{llllllllll}
\hline Species & \multicolumn{3}{l}{ Total soluble N (\% of dry weight) } & \multicolumn{3}{l}{ Total N (\% of dry weight) } & \multicolumn{2}{l}{ C:N ratio } \\
\hline Lolium perenne & 0.84 & \pm & 0.12 & 3.2 & \pm & 0.2 & 14.3 & \pm & 0.7 \\
Phleum pratense & 0.37 & \pm & 0.03 & 2.7 & \pm & 0.03 & 17.3 & \pm & 0.2 \\
Festuca pratensis & 0.62 & \pm & 0.06 & 3.1 & \pm & 0.1 & 14.5 & \pm & 0.4 \\
Lolium multiflorum & 0.46 & \pm & 0.07 & 2.9 & \pm & 0.1 & 15.2 & \pm & 0.5 \\
Dactylis glomerata & 0.55 & \pm & 0.02 & 3.1 & \pm & 0.2 & 15.0 & \pm & 0.4 \\
Holcus lanatus & 0.45 & \pm & 0.04 & 3.0 & \pm & 0.1 & 14.6 & \pm & 0.4 \\
Bromus mollis & 0.55 & \pm & 0.08 & 3.4 & \pm & 0.1 & 13.2 & \pm & 0.3 \\
\hline
\end{tabular}

higher values $(0.2-0.9 \mathrm{mM})$ were measure in an intensively managed Lolium perenne grassland in the Netherlands (Loubet et al., 2002; van Hove et al., 2002). However, following application of nitrogen fertilizer, also the apoplastic $\mathrm{NH}_{4}^{+}$ concentrations of the grass mixture in the present field increased to around $0.9 \mathrm{mM}$ (Mattsson et al., 2008). Apoplastic $\mathrm{pH}$ differed about one $\mathrm{pH}$ unit between the species with the lowest value (Phleum pratense; $\mathrm{pH} 6.0$ ) and the highest value (Dactylis glomerata; pH 6.9). Over the period from January to November, van Hove et al. (2002) observed apoplastic pH values in Lolium perenne ranging between 5.9 and 6.5.

The three species Lolium perenne, Festuca pratensis and Dactylis glomerata, which had the highest apoplastic $\mathrm{NH}_{4}^{+}$ concentrations, also exhibited the highest apoplastic $\mathrm{pH}$ values (Fig. 2). The resulting $\mathrm{NH}_{3}$ compensation points for these three species were $3.5,6.5$ and $5 \mathrm{nmol} \mathrm{mol}^{-1}$, respectively. These compensation points are in agreement with results derived from laboratory cuvette studies, which showed $\mathrm{NH}_{3}$ compensation points of 5.0 and $6.8 \mathrm{nmol} \mathrm{mol}^{-1}$ for Lolium perenne and Bromus erectus, respectively, growing with a high concentration $(3 \mathrm{mM})$ of $\mathrm{NO}_{3}^{-}$in the nutrient solution (Mattsson and Schjoerring, 2002).

The atmospheric $\mathrm{NH}_{3}$ concentration $1 \mathrm{~m}$ above ground during the period of apoplastic measurements (24 and 25 May 2000) was 3 to $4.5 \mathrm{nmol} \mathrm{mol}^{-1}$ (corresponding to 2.1 to $3.2 \mu \mathrm{g} \mathrm{m}^{-3}$ ). Since this value was lower than the predicted $\mathrm{NH}_{3}$ compensation points, episodes of $\mathrm{NH}_{3}$ emission would be expected, particularly since the total abundance of the three species with highest $\mathrm{NH}_{3}$ compensation points was more than $70 \%$ (Fig. 1). Actually, $\mathrm{NH}_{3}$ emission was measured around noon of 25 May, i.e. simultaneously with the sampling of the leaf material. Prior to cutting of the grass on 29 May, the $\mathrm{NH}_{3}$ exchange pattern was dominated by small bi-directional fluxes ( -64 to $42 \mathrm{ng} \mathrm{NH}_{3} \mathrm{~m}^{-2} \mathrm{~s}^{-1}$; Milford et al., 2008). The predicted $\mathrm{NH}_{3}$ compensation of the dominating species Lolium perenne $\left(3.5 \mathrm{nmol} \mathrm{mol}^{-1}\right)$ was very close to the measured atmospheric $\mathrm{NH}_{3}$ concentrations in the period. Festuca pratensis with the highest $\mathrm{NH}_{3}$ compensation point of $6.5 \mathrm{nmol} \mathrm{mol}^{-1}$ only accounted for $10 \%$ of the canopy in the experimental field and would thus not be able to exert a major influence on the $\mathrm{NH}_{3}$ exchange of the whole field. Furthermore, atmospheric $\mathrm{NH}_{3}$ and/or $\mathrm{NH}_{3}$ emitted from species with a high $\mathrm{NH}_{3}$ compensation point may have been absorbed by some of the species with a low $\mathrm{NH}_{3}$ compensation points such as Phleum pratense (Fig. 3) which had a fairly high abundance in the field (Fig. 1). Based on data from apoplastic measurements in intensively managed Lolium perenne grassland in the Netherlands, van Hove et al. (2002) estimated stomatal $\mathrm{NH}_{3}$ compensation points varying between 0.7 and $6 \mathrm{nmol} \mathrm{mol}^{-1}$ over the period from January to November. The gaseous $\mathrm{NH}_{3}$ concentrations inside the grass leaves were, with a few exceptions, always smaller than the measured ambient $\mathrm{NH}_{3}$ concentrations indicating that the grass canopy was unlikely to be a major source of $\mathrm{NH}_{3}$ emission. In a study over non-fertilized managed grassland in The Netherlands, $\mathrm{NH}_{3}$ emission fluxes were frequent (about $50 \%$ of the time) during a warm, dry summer period, while in a wet, cool autumn period deposition fluxes dominated ( $80 \%$ of the time) due to small canopy compensation points caused by low temperatures and a generally wet surface (Wichink Kruit et al., 2007).

Leaf tissue $\mathrm{NH}_{4}^{+}$concentration ranged from 0.5 to $1.8 \mu \mathrm{mol} \mathrm{g}^{-1} \mathrm{FW}$ (fresh weight) with the highest values obtained for the same three species that were in the top with respect to apoplastic $\mathrm{NH}_{4}$ concentration. $\mathrm{NO}_{3}^{-}$concentrations were really high only in Lolium perenne (Fig. 4). Phleum pratense had low concentrations of both $\mathrm{NH}_{4}^{+}$and $\mathrm{NO}_{3}^{-}$. Grass species are known to differ in their tendency to accumulate nitrate (Wilman and Wright, 1986) and particularly after fertilization when average leaf tissue $\mathrm{NO}_{3}^{-}$concentrations increased to $40-50 \mu \mathrm{mol} \mathrm{g}^{-1} \mathrm{FW}$ (Mattsson et al., 2008) the differences between species could have been more pronounced. Both soluble $\mathrm{N}$ and total $\mathrm{N}$ concentrations were also very low in Phleum pratense which led to an extremely high $\mathrm{C}: \mathrm{N}$ ratio of 17.3 in the herbage compared to the other grass species (Table 2). On the other hand, Bromus mollis, which also showed low leaf tissue $\mathrm{NH}_{4}^{+}$and $\mathrm{NO}_{3}^{-}$concentrations, had the highest total $\mathrm{N}$ concentration in the leaves and therefore the lowest $\mathrm{C}: \mathrm{N}$ ratio. 
In the present investigation a clear linear relationship existed between leaf tissue $\mathrm{NH}_{4}^{+}$concentration and apoplastic $\Gamma$ values across species, but not between substrate $\mathrm{N}$ and $\Gamma$. Thus, tissue $\mathrm{NH}_{4}^{+}$concentration proved to be a more promising indicator of $\mathrm{NH}_{3}$ emission potential than substrate $\mathrm{N}$. Similar correlations were also found for apoplastic and leaf tissue $\mathrm{NH}_{4}^{+}$samples over a diurnal course (Herrmann et al., 2008) and over the entire experimental time course with different management events (Mattsson et al., 2008). The ratio between leaf tissue and apoplast $\mathrm{NH}_{4}^{+}$concentration was for most species around 30 (Figs. 2 and 4). However, in Holcus lanatus and Bromus mollis, which contained a very low concentration of apoplastic $\mathrm{NH}_{4}^{+}$, this ratio was much higher. Prediction of $\mathrm{NH}_{3}$ exchange potential from leaf tissue $\mathrm{NH}_{4}^{+}$ concentrations might therefore be problematic in some cases.

\section{Conclusions}

We conclude that grass species growing on the same field can differ greatly with respect to foliar $\mathrm{N}$ pools. Variations among grass species in apoplastic $\mathrm{pH}$ and $\mathrm{NH}_{4}^{+}$concentrations may result in very different $\mathrm{NH}_{3}$ compensation points. Species with high abundance and $\mathrm{NH}_{3}$ compensation points around the level of atmospheric $\mathrm{NH}_{3}$ concentrations may contribute to bi-directional $\mathrm{NH}_{3}$ fluxes over the whole field, while species with considerably lower $\mathrm{NH}_{3}$ compensation points only will contribute to $\mathrm{NH}_{3}$ absorption from the atmosphere. In the present work, three species (Lolium perenne, Festuca pratensis and Dactylis glomerata) were likely to contribute to small $\mathrm{NH}_{3}$ emissions (up to $42 \mathrm{ng} \mathrm{NH}_{3} \mathrm{~m}^{-2} \mathrm{~s}^{-1}$ ) measured over the whole field during the day time. Leaf tissue $\mathrm{NH}_{4}^{+}$concentrations were well correlated with the ratio between apoplastic $\mathrm{NH}_{4}^{+}$and $\mathrm{H}^{+}$ concentrations suggesting that leaf tissue $\mathrm{NH}_{4}^{+}$can be used for predicting the $\mathrm{NH}_{3}$ exchange potential.

Acknowledgements. The authors gratefully acknowledge the support of many different funders and colleagues to this work. The measurements were conducted under the frame of the GRAMINAE project funded by the European Commission (ENV4-CT98-0722). The final analysis of results was conducted under the EC NitroEurope Integrated Project.

Edited by: F. X. Meixner

\section{References}

Bullock, J. M., Pywell, R. F., and Walker, K. J.: Long-term enhancement of agricultural production by restoration of biodiversity, J. Appl. Ecol., 44, 6-12, 2007.

Clark, C. M., Cleland, E. E , Collins, S. L., Fargione, J. E., Gough, L., Gross, K. L., Pennings, S. C., Suding, K. N., and Grace, J. B.: Environmental and plant community determinants of species loss following nitrogen enrichment, Ecol. Lett., 10, 596-607, 2007.
Cleland, E. E., Chiariello, N. R., Loarie, S. R., Mooney, H. A., and Field, C. B.: Diverse responses of phenology to global changes in a grassland ecosystem, Proc. Natl. Acad. Sci. USA, 103, 1374013744, 2006.

Critchley, C. N. R, Chambers, B. J., Fowbert, J. A., Sanderson, R. A., Bhogal, A., and Rose, S. C.: Association between lowland grassland plant communities and soil properties, Biol. Conserv., 105, 199-215, 2002.

Critchley, C. N. R., Fowbert, J. A., and Wright, B.: Dynamics of species-rich upland hay meadows over 15 years and their relation with agricultural management practices, Appl. Veg. Sci., 10, 307-314, 2007.

David, M., Loubet, B., Cellier, P., Mattsson, M., Schjoerring, J. K., Nemitz, E., Roche, R., Riedo, M., and Sutton, M.A.: Ammonia sources and sinks in an intensively managed grassland using dynamic chambers, Biogeosciences Discuss., accepted, 2008.

Ellenberg, H., Weber H. E., Düll, R., Wirth, V., Werner, W., and Paulissen, D.: Indicator values of plants in Central Europe, Scripta Geobotanica, 18, 1, 1-248, 1991.

Genfa, Z., Dasgupta, P. K., and Dong, S.: Measurement of atmospheric ammonia, Environ. Sci. Technol., 23, 1467-1474, 1989.

Hanstein, S., Mattsson, M., Jaeger, H.-J., and Schjoerring, J. K.: Uptake and utilization of atmospheric ammonia in three native Poaceae species: Leaf conductances, composition of apoplastic solution and interactions with nitrogen supply, New Phytol., 141, 71-83, 1999.

Harpole, W. S., Potts, D. L., and Suding, K. N.: Ecosystem responses to water and nitrogen amendment in a California grassland, Global Change Biol., 13, 2341-2348, 2007.

Herrmann, B., Jones, S. K., Fuhrer, J., Feller, U., and Neftel, A.: N budget and $\mathrm{NH}_{3}$ exchange of a grass/clover crop at two levels of N application, Plant Soil, 235, 243-252, 2001.

Hill, J. O., Simpson, R. J., Wood, J. T., Moore, A. D., and Chapman, D. F.: The phosphorus and nitrogen requirements of temperate pasture species and their influence on grassland botanical composition, Aust. J. Agric. Res., 56, 1027-1039, 2005.

Hill, M. O. and Carey, P. D.: Prediction of yield in the Rothamsted Park Grass Experiment by Ellenberg indicator values, J. Veg. Sci., 8, 579-586, 1997.

Hill, P. W., Raven, J. A., Loubet, B., Fowler, D., and Sutton, M. A.: Comparison of gas exchange and bioassay determinations of the ammonia compensation point in Luzula sylvatica (Huds.) Gaud., Plant Physiol., 125, 476-487, 2001.

Hopkins, A.: Botanical composition of permanent grassland in England and wales in relation to soil, environment and management factors, Grass Forage Sci., 41, 237-246, 1986.

Husted, S. and Schjoerring, J. K.: Apoplastic pH and ammonium concentration in leaves of Brassica napus L., Plant Physiol., 109, 1453-1460, 1995.

Husted, S. and Schjoerring, J. K.: Ammonia flux between oilseed rape plants and the atmosphere in respons to changes in leaf temperature, light intensity, and air humidity, Plant Physiol., 112, 67-74, 1996.

Husted, S., Schjoerring, J. K., Nielsen, K. H., Nemitz, E., and Sutton, M. A.: Stomatal compensation points for ammonia in oilseed rape plants under field conditions, Agr. Forest Meteorol., 105, 371-383, 2000a.

Husted, S., Hebbern, C. A., Mattsson, M., and Schjoerring, J. K.: Determination of ammonium, low molecular weight amines and 
amides in plant tissue, Physiol. Plant., 109, 167-179, $2000 \mathrm{~b}$.

Klimek, S., Kemmermann, A. R. G., Hofmann, M., and Isselstein, J.: Plant species richness and composition in managed grasslands: The relative importance of field management and environmental factors, Biol. Conserv., 134, 559-570, 2007.

Knapp, R. (Ed.): Sampling methods in taxon analysis in vegetation science, Handbook of Vegetation Science 1. Part 4, Junk, Hague, The Netherlands, 1984.

Lohaus, G., Pennewiss, K., Sattelmacher, B., Hussmann, M., and Muehling, K. H.: Is the infiltration-centrifugation technique appripriate for isolation of apoplastic fluid? A critical evaluation with different plant species, Physiol. Plant., 111, 457-465, 2001.

Loubet, B., Milford, C., Hill, P. W., Tang, Y. S., Cellier, P., and Sutton, M. S.: Seasonal variability of apoplastic $\mathrm{NH}_{4}^{+}$and $\mathrm{pH}$ in an intensively managed grassland, Plant Soil, 238, 97-110, 2002.

Mattsson, M., Häusler, R. E., Leegood, R. C., Lea, P., and Schjoerring, J. K.: Leaf-atmosphere ammonia exchange in barley mutants with reduced activities of glutamine synthetase, Plant Physiol., 114, 1307-1312, 1997.

Mattsson, M., Husted, S., and Schjoerring, J. K.: Influence of nitrogen nutrition and metabolism on ammonia volatilization in plants, Nutr. Cycl. Agroecosys., 51, 35-40, 1998.

Mattsson, M. and Schjoerring, J. K.: Dynamic and steady state responses of inorganic nitrogen pools and $\mathrm{NH}_{3}$ exchange in leaves of Lolium perenne and Bromus erectus to changes in root $\mathrm{N}$ supply, Plant Physiol., 128, 742-750, 2002.

Mattsson, M., Herrmann, B., David, M., Loubet, B., Riedo, M., Theobald, M. R., Sutton, M. A., Bruhn, D., Neftel, A., and Schjoerring, J. K.: Temporal variability in bioassays of ammonia exchange potential in relation to plant and soil nitrogen parameters in intensively managed grassland, Biogeosciences Discuss., 5, 2749-2772, 2008,

http://www.biogeosciences-discuss.net/5/2749/2008/

Milford, C., Theobald, M. R., Nemitz, E., Hargreaves, K. J., Horvath, L., Raso, J., Dämmgen, U., Neftel, A., Jones, S. K., Hensen, A., Loubet, B., Cellier, P., and Sutton, M. A.: Ammonia fluxes in relation to cutting and fertilization of an intensively managed grassland derived from an inter-comparison of gradient measurements, Biogeosciences Discuss., 5, 4699-4744, 2008, http://www.biogeosciences-discuss.net/5/4699/2008/.

Mountford, J. O., Lakhani, K. H., and Kirkham, F. W.: Experimental assessment of the effects of nitrogen addition under haycutting and aftermath grazing on the vegetation of medows on a Somerset peat moor, J. Appl. Ecol., 30, 321-332, 1993.

Nielsen, K. H. and Schjoerring, J. K.: Regulation of apoplastic $\mathrm{NH}_{4}^{+}$concentration in leaves of oilseed rape, Plant Physiol., 118, 1361-1368, 1998.

Oelmann, Y., Wilcke, W., Temperton, V. M., Buchmann, N., Roscher, C., Schumacher, J., Schulze, E. D., and Weisser, W. W.: Soil and plant nitrogen pools as related to plant diversity in an experimental grassland, Soil Sci. Soc. Am. J., 71, 720-729, 2007.
Pontes, L. S., Carrere, P., Andueza, D., Louault, F., and Soussana, J. F.: Seasonal productivity and nutritive value of temperate grasses found in semi-natural pastures in Europe: responses to cutting frequency and N supply, Grass Forage Sci., 62, 485-496, 2007.

Pywell, R. F., Bullock, J. M., Tallowin, J. B., Walker, K. J., Warman, E. A., and Masters, G.: Enhancing diversity of species-poor grasslands: an experimental assessment of multiple constraints, J. Appl. Ecol., 44, 81-94, 2007.

Schjoerring, J. K. and Mattsson, M.: Quantification of ammonia exchange between agricultural cropland and the atmosphere: Measurements over two complete growth cycles of oilseed rape, wheat, barley and pea, Plant Soil, 228, 105-115, 2001.

Silvertown, J: The dynamics of a grassland ecosystem: botanical equilibrium in the Park grass experiment, J. Appl. Ecol., 17, 491504, 1980.

Silvertown, J., Poulton, P., Johnston, E., Edwards, G., Heard, M., and Biss, P. M.: The Park Grass Experiment 1856-2006: Its contribution to ecology, J. Ecol., 94, 801-814, 2006.

Stevens, C. J., Dise, N. B., Gowing, D. J. G., and Mountford, J. O.: Loss of forb diversity in relation to nitrogen deposition in the UK: regional trends and potential controls, Global Change Biol., 12, 1823-1833, 2006.

Stevens, C. J., Dise, N. B., Mountford, J. O., and Gowing, D. J.: Impact of nitrogen deposition on the species richness of grasslands, Science, 303, 1876-1879, 2004.

Sutton, M. A., Nemitz, E., Theobald, M. R., Milford, C., Dorsey, J. R., Gallagher, M. W., Hensen, A., Jongejan, P. A. C., Erisman, J. W., Mattsson, M. E., Schjoerring, J. K., Cellier, P., Loubet, B., Roche, R., Neftel, A., Hermann, B., Jones, S., Lehman, B. E., Horvath, L., Weidinger, T., Rajkai, K., Burkhardt, J., Löpmeier, F. J., and Daemmgen, U.: Dynamics of ammonia exchange with cut grassland: strategy and implementation of the GRAMINAE Integrated Experiment, Biogeosciences Discuss., 5, 3347-3407, 2008 , http://www.biogeosciences-discuss.net/5/3347/2008/.

van Hove, L. W. A., Heeres, P., and Bossen, M. E.: The annual variation in stomatal ammonia compensation point of rye grass (Lolium perenne L.) leaves in an intensively managed grassland, Atmos. Environ., 36, 2965-2977, 2002.

Whitehead, D. C.: Grasses: Uptake of nitrogen and effects on morphology and physiology, in: Grassland nitrogen, CAB International, edited by: Whitehead, D. C., UK, 16-34, 1995.

Wichink Kruit, R. J., van Pul, W. A. J., Otjes, R. P., Hofschreuder, P., Jacobs, A. F. G., and Holtslag, A. A. M.: Ammonia fluxes and derived canopy compensation points over non-fertilized agricultural grassland in The Netherlands using the new gradient ammonia-high accuracy-monitor (GRAHAM), Atmos. Environ., 41, 1275-1287, 2007.

Wilman, D. and Wright, P. T.: The effect of interval between harvests and nitrogen application on the concentration of nitratenitrogen in the total herbage, green leaf and "stem" of grasses, J Agric. Sci., Cambridge, 106, 467-475, 1986. 